\title{
The right digital strategy for your business: an empirical analysis of the design and implementation of digital strategies in SMEs and LSEs
}

\author{
Wolfgang Becker ${ }^{1} \cdot$ Oliver Schmid $^{1}$
}

Received: 18 October 2019/Accepted: 25 August 2020/Published online: 11 September 2020

(C) The Author(s) 2020

\begin{abstract}
The importance of digitalization continues to grow, with companies from all sectors and of various sizes subject to this influence. To remain competitive in the future, companies must recognize and overcome the opportunities and challenges of digitalization in the long term. To do this, companies can develop an entire digitization strategy that affects all areas of the business, enabling them to achieve a holistic digital transformation and ensure their survival in the digital age. Based on a qualitative-empirical research design, this study examines whether small and medium-sized enterprises (SMEs) and large enterprises (LSEs) have such a strategy, and how it is structured. In particular, it addresses the use of new technology, changes in value added, structural changes and the financing of digitalization. At the same time, there is an examination of any similarities and differences among the different company sizes.
\end{abstract}

Keywords Digital strategy $\cdot \mathrm{SME} \cdot \mathrm{LSE}$

\section{Introduction}

Since the era of the post-dotcom decade, technological change and the associated digitalization have become increasingly important (Haffke 2017). These new technological developments have not influenced individual companies or specific industries (Westermann et al. 2012; Haffke et al. 2016; Hess et al. 2016; Laumer et al. 2016; Sia et al. 2016), but, in combination with ever-changing customer needs,

Oliver Schmid

oliver.schmid@uni-bamberg.de

Wolfgang Becker

wolfgang.becker@uni-bamberg.de

1 Feldkirchenstr. 21, 96052 Bamberg, Germany 
have had, and are having, an impact on the economy and society as a whole (Diamandis 2015; Haffke et al. 2016]. Ultimately, these changing customer needs and customer behaviors are critical to any business, as customers increasingly expect customized products, services and new, unique customer experiences (Vey et al. 2017).

Conversely, for businesses, this means that they have "to adapt their business infrastructure to the new digital era" (Bharadwaj et al. 2013, p. 472), which means that they must adapt their entire value chain to the new technology and digital requirements since the nature of value added has evolved (Porter and Heppelmann 2015; Klötzer and Pflaum 2017). This shows that in the future companies will have to develop business models that differentiate them from their current business models, and those of their competitors, by integrating and using new technologies to ensure the successful survival of companies in the digital future (Bharadwaj et al. 2013; Hess et al. 2016; Vey et al. 2017; Becker et al. 2018). In order for companies to tap into their full value-creation potential in times of digitalization, they need a clearly defined strategic orientation, by which future (digital) business models can be implemented. What matters here is not when, but how, companies carry out their digital transformation (Hess et al. 2016). Appropriate strategic alignment in times of digitalization at the enterprise level takes advantage of the benefits gained from the use of new digital technologies and enables the management in the company to transform them through digital initiatives and the resulting products and services (Ross et al. 2017). The company's strategic focus on digitalization is done with the intention of realizing cost advantages, unlocking additional sales potential, increasing productivity and developing new business models (Hess et al. 2016). A clear strategy that takes into account the use of digital technologies is, therefore, crucial for the future business success of companies of all sizes and industries (Hess et al. 2016).

In recent decades, however, a digital strategy, insofar as there has been a separate strategy with a digital focus at all, has rather been subordinated to a functional business strategy or equated to the overall corporate strategy (Reich and Benbasat 2000; Hirschheim and Sabherwal 2001; Sabherwal and Chan 2001). Today, a digital strategy is much more, because digital technologies or connectivity are fundamentally transforming traditional business strategies into modular and cross-functional global strategies that enable business processes to be established beyond the boundaries of time, distance or function (Wheeler 2002; Sambamurphy et al. 2003; Banker et al. 2006; Kohli and Grover 2008). Thus, a digital strategy is a business strategy that is inspired by the power of high-performance, easily accessible technologies while providing unique, integrated business functions in a way that can adapt to ever-changing market conditions (Sebastian et al. 2017). Therefore, companies that want to survive in the digital age need a comprehensive overall strategy that includes all the digital resources of their business (Bharadwaj et al. 2013).

Because every company in every industry and of every size is affected by digitalization (Westermann et al. 2012), all companies must deal with their strategic orientation and develop a digital strategy that is right for them. Recent scientific research has shown that digital strategies are a highly current research topic 
(Bharadwaj et al. 2013; Pagani 2013; Woodard et al. 2013; Matt et al. 2015; Hess et al. 2016; Mithas et al. 2016), which is currently at an early stage of investigation (Mithas et al. 2016). In scientific research different approaches to defining terms are also discussed (Bharadwaj et al. 2013; Woodard et al. 2013; Hess et al. 2016; Mithas et al. 2016; Sebastian et al. 2017). Furthermore, Mithas et al. (2016) investigate in their study how a digital strategy arises when the competition of a company influences the digital strategic position. At the same time, Pagani (2013) describes the approaches by which added value can be created by digital strategies and appropriated in digitally enabled networks impacted by technological changes. Matt et al. (2015) also deduced which components should have a digital strategy.

What is striking about the current scientific literature is that all the studies that were conducted on the subject were carried out on the basis of a qualitative research design with companies of different sizes or sectors (see e.g. Hess et al. 2016; Woodard et al. 2013). No study has focused on companies of a specific size, thereby highlighting a current research gap.

This means that large-scale companies (LSEs) must also deal with the topic of digital strategy since a large number of the traditional LSEs are still at the beginning of their digital transformation and most of them still generate their sales from traditional products and services (Sebastian et al. 2017). Born digitals, such as Amazon, Facebook or Google, have become strong competitors for LSEs by using modern technologies to attack the traditional, mostly analogue business model and the way in which big old companies add value (Sebastian et al. 2017). This shows that LSEs have to deal with the topic of digitalization and a corresponding strategic direction to continue to be competitive in the digital era.

Furthermore, small and medium-sized enterprises (SMEs), which play a crucial and important role in the European economy (Li et al. 2016) and are considered engines of economic growth (Lee et al. 2012), face the same challenges as LSEs. This means that they are also influenced by digitalization and the associated digital transformation of their respective business models since the way to create and capture value has changed in the digital age (Bharadwaj et al. 2013; Lucas et al. 2013; Klötzer and Pflaum 2017). To remain competitive, this ultimately means that SMEs also have to rethink their strategic direction and, in particular, their digital strategy and adapt them to the changed underlying situational conditions (Bouwman et al. 2017) insofar as such a strategy exists in these companies. However, SMEs differ significantly from LSEs in terms of their limited financial scope, fewer welltrained staff and fewer resources (Pullen et al. 2009; Bidan et al. 2012).

Therefore, it can be assumed that there are essential differences within the strategic orientation of SMEs and LSEs as a result of the different characteristics of SMEs and LSEs in the digital age. For this reason, the present study investigates the following two main research questions:

1. Do SMEs and LSEs have a digital strategy, and how is it structured?

2. Are there differences and/or similarities between digital strategies in SMEs and LSEs?

Following these research questions, the present study has the following structure: Chapter 1 presents the current problem facing the theoretical framework, based on 
the research of Matt et al. (2015). Chapter 3 presents the research methodology and data analysis. Chapter 4 presents the results of the study. In particular, it discusses the purpose of SMEs and LSEs, with their digital strategy and its design regarding the use of new technology, changes in value added, structural changes and the financing of digitalization. Chapter 5 discusses the findings and derives ideal-type digital strategies for SMEs or LSEs before the study concludes in Chapter 6 and outlines future research.

\section{Theoretical framework}

For this reason, such a strategy is an overall construct of an IT-driven digital strategy and a business strategy (Woodard et al. 2013; Mithas et al. 2016), where there is a reciprocal relationship between the two strategies (Bharadwaj et al. 2013; Hess et al. 2016). A so-called digital business strategy arises when it includes competition-related activities to offer digital products and services (Yeow et al. 2017). To successfully master digital transformation and thus ensure future survival in times of digitalization, companies need to have a digital strategy that suits them. To formulate a digital strategy, companies use the so-called "digital transformation framework", according to Matt et al. (2015). The authors describe in their article that it is first necessary to clarify "which content aspects digital transformation strategies should consist of" (Matt et al. 2015, p. 3). Regardless of the industry or company, such digital strategies have similarities in the following: (1) the use of technologies, (2) changes in value creation, (3) structural changes, and (4) the financial dimension (Fig. 1).

1. To develop a digital strategy, companies must first recognize the strategic role of new IT and be able to develop and exploit it. In particular, it is crucial whether companies make use of technology that already exists on the market or whether they act as market leaders through their own creation of new technology. Horlacher and Hess (2016) and Becker et al. (2018) come to the same conclusion in their studies because they found that companies of all sizes_including both SMEs and LSEs-have to understand the role of new digital technologies, as these can disruptively change the existing business model. In addition, these new digital technologies result in new opportunities, but also threats for all company sizes (Haffke et al. 2016; Leischnig et al. 2016).

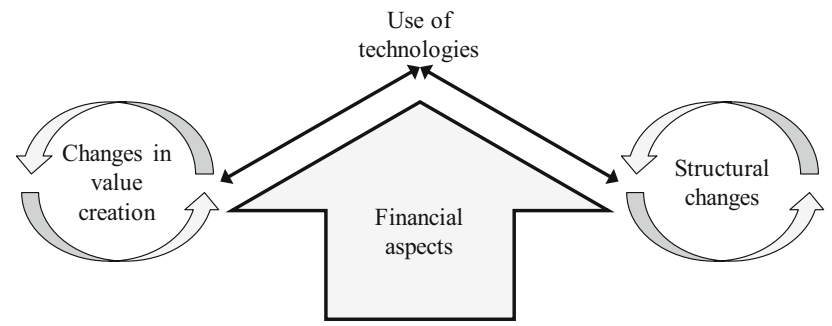

Fig. 1 Digital transformation framework according to Matt et al. (2015) 
Especially financial resources make it easier for LSEs to scout and purchase new digital technologies and IT than SMEs. Often a company-wide overall solution is too expensive for SMEs and usually offers only rudimentary solutions for very specific problems. However, SMEs can integrate new technologies much faster and easier due to their size, whereas in LSEs the integration of new technologies usually involves a long-term planning and implementation phase.

2. Technological change often leads to changes in the creation of added value, as these have an impact on the entire value chain of companies. Companies have to ask themselves about the extent to which their new (digital) activities deviate from the classic, analogue core business and which markets or customers are targeted. Moreover, research shows that the nature of value creation has shifted from classical physical products to "smart" products and data (Klötzer and Pflaum 2017; Sebastian et al. 2017). For companies, this means they can expand their current product and service offerings, often requiring an increased need for technological and product-related know-how. On the other hand, there is an increased risk in companies because they often have less experience in these new areas. Both SMEs and LSEs must therefore be clear about how they will create added value in the digital future, since the competitive situation, in particular, has shifted due to new, partly purely digital companies. Meanwhile, new players not only attack SMEs and their business models but also compete directly with large, traditional companies and their performing business models that have been successful for decades due to their market position (Bharadwaj et al. 2013; Sebastian et al. 2017). For SMEs in particular, a successful orientation of future value creation is crucial, since here, due to the often limited financial and human resources, no short-term change in the fundamental way of value creation is possible. Due to their size, financial and human resources and according to market power, LSE can react much more easily to such changes in the creation of value, even at short term.

3. The integration of new technology and the changing value creation requires a suitable organizational structure in the company to successfully implement the challenges of the digital transformation and the associated tasks. Here, the entire corporate organizational design must be adapted to the new circumstances by optimally integrating the new digital activities within the corporate structures and their influence on products, processes or skills in the company. In this way, companies can integrate new tasks into existing structures, as well as into newly created areas (especially in the case of substantial changes). SMEs and LSEs, in particular, need a suitable organizational and management structure to implement the digital transformation (Horlacher and Hess 2016; Köhler and Hess 2016). Meanwhile, the integration of new (digital) technologies requires "different mindsets and skill sets than previous waves of transformative technology" (Fitzgerald et al. 2013, p. 6). For both SMEs and LSEs, the "war of talents"- the struggle for suitable personnel is extremely high. Furthermore, an agile organizational structure coupled with flexible and agile working methods is also crucial here (Nowotarskia and Paslawski 2015) to be able to implement faster changes due to the digital transformation. For this 
reason, it can be assumed that, in contrast to LSEs, SMEs, in particular, have flatter and more agile hierarchies due to their size and that changes with regard to digitalization and the establishment of a digital strategy can be implemented faster and more easily.

4. To be able to realize these changes, financial aspects have to be considered, because "financial aspects are both a driver of and a bounding force of the transformation" (Matt et al. 2015, p. 4). The financing of the digital transformation can be done from both within the company and outside through external opportunities. SMEs, in particular, are faced with the challenge of using them in a purpose-oriented manner without already having limited financial and human resources. LSEs, on the other hand, have significant advantages over smaller companies due to their company size and financial and market power, since misinvestments can also be absorbed here; SMEs, on the other hand, generally do not have such "financial cushions" or "play money" for digital transformation (Pullen et al. 2009; Bidan et al. 2012).

For the digital transformation to be successful, it is essential that all four dimensions of the digital transformation framework are aligned. The explanations show that both SMEs and LSEs are influenced by digitalization in all four dimensions.

\section{Methodology and data analysis}

This chapter introduces the research design and data analysis. In the context of information systems, it is recommended in science to conduct a qualitative research design based on case studies (Dubé and Paré 2003; Arnold et al. 2016). First, this research method is presented before the sampling of the present study and the data collection and data analysis are presented.

\subsection{Research design}

Because the design of digital strategies in SMEs and LSEs is still a young and largely unexplored area, this study used a qualitative, exploratory research design based on several expert interviews with 29 executives who are responsible for digital leadership in SMEs and LSEs. In IS research, in particular, the use of qualitative interview methods is a common procedure, since it enables various currently relevant research topics to be examined (Eisenhardt and Graebner 2007), especially in areas in which there is currently very little a priori research (Siggelkow 2007). This paper follows the approach according to Eisenhardt (1989) and Yin (2014). In contrast to an individual case, this approach allows much more general results to be derived on a stronger basis by using interview data with several companies across a variety of situational contexts (Eisenhardt 1989; Yin 2014).

This research approach makes it possible to examine areas of research that are still in an early phase of investigation, using detailed questions such as "how", "who" and "why" (Yin 2014). As a result, the verbalized business experience can 
be achieved. This information is characterized by a high degree of detail and quality, as the result of a much smaller sample than in quantitative investigation designs; this information, therefore, has a higher intrinsic value. To further increase the meaningfulness of this information, internal and external data, including interviews, press releases, management reports or comments by industry experts, were also consulted. For this reason, this information is often preferred to information from quantitative research (Foddy 1993). The descriptions obtained by the open procedures from the guided interviews allow a holistic description of unknown areas of research. In addition, conclusions and recommendations can be derived (Yin 2014).

Overall, therefore, a qualitative research design was suitable for the present problem, as it allowed a description of the "black box" regarding the design of digital strategies in SMEs and LSEs. In this way, the present study contributes further to science and practice in the context of the digital transformation of companies (Amit and Zott 2001; Doz 2011; Arnold et al. 2016).

\subsection{Sampling}

In the scientific literature, in the context of qualitative research, a case number of 4-10 interviews is recommended for reasons of complexity (Eisenhardt 1989). To holistically investigate the field of research on digital strategies in SMEs and LSEs, this number was deliberately exceeded.

Table 1 shows the companies, with the respective study participants. The classification of companies was based on the size categories of the European Competence Center for Applied SME Research (Simon 1992; Becker et al. 2018). Companies with a number of employees up to 3,000 represented SMEs, as long as their annual revenue did not exceed 600 million euros.

In total, 29 companies participated in the study. The study participants indicated the industry, legal form, number of employees and revenue of their companies. Nine companies had fewer than 300 employees and less than 60 million euros in sales and therefore represented small companies. Ten other companies had between 300 and 3000 employees and between 60 and 600 million euros (excluding SME 16 and 17). These companies were therefore classified as medium-sized companies. For reasons of simplification, the 9 small and 10 medium-sized enterprises were grouped into 19 SMEs (SME 1 to SME 19). Another 10 companies had more than 3,000 employees and more than 600 million euros in revenue; these were classified as LSEs (LSE 1 to LSE 10). In the SMEs, the average number of employees was 601 and the arithmetic mean of the revenue was 148.21 million euros, of which an average share of approximately $37.6 \%$ was based on purely digital sales. In contrast, the LSEs participating in the study had an average of 72,400 employees and an average turnover of 13178.91 million euros. In the LSEs the relative digital sales averaged around $30.6 \%$.

To guarantee their anonymity, participants were anonymized, because every participant could either be a male or a female person. For reasons of simplification, the participants are considered to be masculine in this paper. 
Table 1 Companies and participants of the study

\begin{tabular}{|c|c|c|c|c|c|}
\hline \multirow[t]{2}{*}{ Case } & \multicolumn{4}{|l|}{ Company } & \multirow{2}{*}{$\begin{array}{l}\text { Study Participant } \\
\text { Position }\end{array}$} \\
\hline & Industry & Legal & Employees & $\begin{array}{l}\text { Revenues } \\
\text { (EUR } \\
\text { Million) }\end{array}$ & \\
\hline $\begin{array}{c}\text { SME } \\
1\end{array}$ & Media & Ltd & $<300$ & $<60$ & Managing Director \\
\hline $\begin{array}{c}\text { SME } \\
2\end{array}$ & IT & Ltd & $<300$ & $<60$ & Managing Director \\
\hline $\begin{array}{l}\text { SME } \\
3\end{array}$ & IT & Ltd & $<300$ & $<60$ & Managing Director \\
\hline $\begin{array}{c}\text { SME } \\
\quad 4\end{array}$ & Retail & Partnership & $<300$ & $<60$ & Managing Director \\
\hline $\begin{array}{l}\text { SME } \\
5\end{array}$ & Marketing & Partnership & $<300$ & $<60$ & Managing Director \\
\hline $\begin{array}{l}\text { SME } \\
6\end{array}$ & IT & Partnership & $<300$ & $<60$ & Managing Director \\
\hline $\begin{array}{c}\text { SME } \\
7\end{array}$ & Sport & Ltd & $<300$ & $<60$ & Managing Director \\
\hline $\begin{array}{l}\text { SME } \\
8\end{array}$ & $\begin{array}{l}\text { Personnel } \\
\text { Service } \\
\text { Industry }\end{array}$ & Ltd & $<300$ & $<60$ & Employee in Digital Area \\
\hline $\begin{array}{c}\text { SME } \\
9\end{array}$ & Architecture & Ltd & $<300$ & $<60$ & Managing Director \\
\hline $\begin{array}{r}\text { SME } \\
10\end{array}$ & Food Industry & Ltd & $\begin{aligned} 300 & \leq \\
x & <3000\end{aligned}$ & $60 \leq x<600$ & Head of IT Department \\
\hline $\begin{array}{r}\text { SME } \\
11\end{array}$ & Food Industry & $\begin{array}{l}\text { Ltd. \& Limited } \\
\text { Partnership }\end{array}$ & $\begin{aligned} 300 & \leq \\
x & <3000\end{aligned}$ & $60 \leq x<600$ & Commercial Manager \\
\hline $\begin{array}{r}\text { SME } \\
12\end{array}$ & Food Industry & Ltd & $\begin{aligned} 300 & \leq \\
x & <3000\end{aligned}$ & $60 \leq x<600$ & Managing Director \\
\hline $\begin{array}{r}\text { SME } \\
13\end{array}$ & $\begin{array}{c}\text { Electronical } \\
\text { Industry }\end{array}$ & Ltd & $\begin{aligned} 300 & \leq \\
x & <3000\end{aligned}$ & $60 \leq x<600$ & Commercial Manager \\
\hline $\begin{array}{r}\text { SME } \\
14\end{array}$ & Healthcare & Ltd & $\begin{aligned} 300 & \leq \\
x & <3000\end{aligned}$ & $60 \leq x<600$ & Division Manager \\
\hline $\begin{array}{r}\text { SME } \\
15\end{array}$ & $\begin{array}{l}\text { Automotive } \\
\text { and } \\
\text { Software }\end{array}$ & Ltd & $\begin{aligned} 300 & \leq \\
x & <3000\end{aligned}$ & $60 \leq x<600$ & Founder \\
\hline $\begin{array}{r}\text { SME } \\
16\end{array}$ & $\begin{array}{l}\text { Law } \\
\text { Consulting }\end{array}$ & Partnership & $\begin{aligned} 300 & \leq \\
x & <3000\end{aligned}$ & Not Specified & Head of Digitalization \\
\hline $\begin{array}{r}\text { SME } \\
17\end{array}$ & $\begin{array}{l}\text { Financial } \\
\text { Service } \\
\text { Provider }\end{array}$ & $\begin{array}{l}\text { Stock } \\
\text { Company }\end{array}$ & $\begin{aligned} 300 & \leq \\
x & <3000\end{aligned}$ & $\geq 600$ & Financial Consultant \\
\hline $\begin{array}{r}\text { SME } \\
18\end{array}$ & Marketing & Ltd & $\begin{aligned} 300 & \leq \\
x & <3000\end{aligned}$ & $60 \leq x<600$ & Managing Partner \\
\hline $\begin{array}{r}\text { SME } \\
19\end{array}$ & Media & $\begin{array}{l}\text { Stock } \\
\text { Company }\end{array}$ & $\begin{aligned} 300 & \leq \\
x & <3000\end{aligned}$ & $60 \leq x<600$ & $\begin{array}{l}\text { Head of Digital } \\
\text { Development and } \\
\text { Transformation }\end{array}$ \\
\hline $\begin{array}{c}\text { LSE } \\
1\end{array}$ & $\begin{array}{l}\text { Industrial and } \\
\text { Engineering }\end{array}$ & $\begin{array}{l}\text { Stock } \\
\text { Company }\end{array}$ & $\geq 3000$ & $\geq 600$ & $\begin{array}{l}\text { Key Account Manager } \\
\text { Software }\end{array}$ \\
\hline
\end{tabular}


Table 1 continued

\begin{tabular}{|c|c|c|c|c|c|}
\hline \multirow[t]{2}{*}{ Case } & \multicolumn{4}{|l|}{ Company } & \multirow{2}{*}{$\begin{array}{l}\text { Study Participant } \\
\text { Position }\end{array}$} \\
\hline & Industry & Legal & Employees & $\begin{array}{l}\text { Revenues } \\
\text { (EUR } \\
\text { Million) }\end{array}$ & \\
\hline $\begin{array}{c}\text { LSE } \\
2\end{array}$ & IT & $\begin{array}{l}\text { Registered } \\
\text { Company }\end{array}$ & $\geq 3000$ & $\geq 600$ & Head of Digitalization \\
\hline $\begin{array}{c}\text { LSE } \\
3\end{array}$ & IT & $\begin{array}{l}\text { Stock } \\
\text { Company }\end{array}$ & $\geq 3000$ & $\geq 600$ & Head of Enterprise Sales \\
\hline $\begin{array}{c}\text { LSE } \\
4\end{array}$ & $\begin{array}{l}\text { Industrial and } \\
\text { Engineering }\end{array}$ & Ltd & $\geq 3000$ & $\geq 600$ & $\begin{array}{l}\text { Head of Digital } \\
\text { Transformation }\end{array}$ \\
\hline $\begin{array}{c}\text { LSE } \\
5\end{array}$ & $\begin{array}{l}\text { Industrial and } \\
\text { Engineering }\end{array}$ & Ltd & $\geq 3000$ & $\geq 600$ & Head of Lean Production \\
\hline $\begin{array}{c}\text { LSE } \\
6\end{array}$ & Healthcare & Partnership & $\geq 3000$ & Not Specified & Head of IT Department \\
\hline $\begin{array}{c}\text { LSE } \\
7\end{array}$ & Wholesale & $\begin{array}{l}\text { Ltd. \& Limited } \\
\text { Partnership }\end{array}$ & $\geq 3000$ & $\geq 600$ & Sales Director \\
\hline $\begin{array}{c}\text { LSE } \\
8\end{array}$ & IT-Consulting & Ltd & $\geq 3000$ & $\geq 600$ & Technical Account Manager \\
\hline $\begin{array}{c}\text { LSE } \\
9\end{array}$ & $\begin{array}{l}\text { Chemical } \\
\text { Industry }\end{array}$ & $\begin{array}{l}\text { Limited } \\
\quad \text { Partnership }\end{array}$ & $\geq 3000$ & $\geq 600$ & Head of Strategy \\
\hline $\begin{array}{r}\text { LSE } \\
10\end{array}$ & $\begin{array}{l}\text { Research } \\
\text { Industry }\end{array}$ & $\begin{array}{l}\text { Registered } \\
\text { Company }\end{array}$ & $\geq 3000$ & $\geq 600$ & Managing Director \\
\hline
\end{tabular}

\subsection{Data collection and analysis}

Finally, 29 companies and their respective managers were interviewed during the period from November 2017 to January 2018. The interviews lasted an average of $60 \mathrm{~min}$ and took place by means of problem-centered and guideline-based interviews. To ensure reliability and comparability of the results, the researcher used an interview guide based on open questions, so that the statements of the participants could be completely absorbed and not limited by giving their answers. At the same time, the interviewer was able to make appropriate follow-up questions by asking the interviewer to "analyze" the answers in his head during the interviews. In sum, the expert interviews were carried out using a semi-structured questionnaire, with the results being quantitatively evaluated using a content analysis. The evaluation is only an answer option which enables clear statements to be made. In this context, only respective key statements of the participants on the individual subject areas were taken into account.

The guideline consisted of several sections: after introductory information on the company and the person, specific questions on the digital strategy were addressed. In particular, they discussed the purpose of SMEs and LSEs with a digital strategy, 
and whether they already had one. It also examined how a digital strategy was shaped in these companies, focusing particularly on the use of technologies, changes in value creation, structural changes and financial aspects (Matt et al. 2015).

To ensure the accuracy of the statements of the participants, the transcribed statements were returned to the respective participants for release and possible revision. After approval of the participants, the interviews, which were not conducted in English, were translated into English before the data was encoded. The coding process was data-based and inductive, with previous studies on digital strategies being used due to an easier interpretation of the data (see e.g. Matt et al. 2015; Hess et al. 2016).

Analysis was ultimately conducted by two independent researchers using the MAXQDA Plus 12 computer program. A coding pretest was carried out in advance between the two researchers to determine possible coding inconsistencies. With the help of Krippendorff's Alpha (Hayes and Krippendorf 2007) and Cohens Kappa (Cohen 1960), the objectivity and reliability of the intercoder was ensured using matched-pair interview data. The evaluation of the two metrics exceeded the minimum values recommended in the literature (both values are higher than 0.95), from which sufficient objectivity and reliability can be concluded within the framework of the coding (Krippendorf 2004). The interview data was supplemented by available secondary data such as internal and external data, including interviews, press releases, management reports or comments by industry experts. This approach represents a triangulation of the results, which supports the stability of the analysis and interpretation of the results and their validity while increasing their explanatory power. To improve the external validity and increase the generalizability of the statements, a cross-case analysis was carried out in which the interview data were examined several times with regard to certain patterns. The literature also recommends using tables at this point to have a simplified comparison between the cases (Miles and Huberman 1994; Yin 2014).

It should also be noted at this point that the data in the present study is not representative. By focusing on individual key testimonials of the test participants, connections may not be recognizable due to the direct and clear assignment. This problem was countered by the fact that the two researchers critically scrutinized statements and the classification at all times during the conduction of the study. At the same time, this procedure enables the statements to be directly compared across different companies. In addition, the number of SMEs and LSEs was unevenly distributed (19 vs. 10) as the result of a time constraint on the study, whereby for LSEs it was difficult to conduct an adequate number of interviews within the time window.

\section{Results and cross-case analysis}

The following chapter presents the results of the study on the design and implementation of digital strategies in SMEs and LSEs. First, the fundamental purpose and existence of a digital strategy are considered. In line with Matt et al. (2015), the design of such a digital strategy is shown. 


\subsection{Purpose of the digital strategy in SMEs and LSEs}

To obtain a better understanding, the study first examined the purpose of the digital strategy in SMEs and LSEs (Table 2).

The analysis of the study shows that the main purpose of a digital strategy in the SMEs was to optimize internal and external processes $(42 \%)$ or the entire company (42\%). Other reasons for implementing a digital strategy included changing the overall IT systems in the company $(10.5 \%)$ and adjusting them in the business program $(5 \%)$.

In the case of the LSEs, too, the main purpose of a digital strategy was primarily to optimize internal and external processes (60\%). However, the change in the whole company $(20 \%)$ or special individual business areas $(10 \%)$ also played a crucial role. In addition, the digital strategy could also be designed for specific projects $(10 \%)$.

In sum, the present study shows that both the SMEs and LSEs wanted to adapt internal and external processes by developing a digital strategy. At the same time, "the transformation of all processes along the value chain" (SME 8) was decisive. This means that all processes should be optimized "internally throughout the company (...) [as well as] externally with the environment" (LSE2). However, the entire company would also be digitalized by "transforming the existing business model into the digital world, developing new business models to drive the business forward into the future" (SME 19). In line with Hess et al. (2016) and Becker et al. (2018), the study shows that both SMEs and LSEs understood the fundamental idea of the digital transformation and the need for a suitable digital strategy. The basic purpose is to use all the advantages of digital transformation to survive in the digital age. This can be accomplished in particular by optimizing internal and external processes and ultimately also by adapting the entire company with its business $\operatorname{model}(\mathrm{s})$.

Table 2 Purpose of the digital strategy

\begin{tabular}{lllll}
\hline & SMEs & $\begin{array}{l}\text { Percentage } \\
(\%)\end{array}$ & LSEs & $\begin{array}{l}\text { Percentage } \\
(\%)\end{array}$ \\
\hline $\begin{array}{l}\text { Internal and external } \\
\text { processes }\end{array}$ & $\begin{array}{l}1,4,5,8,10,11,13, \\
\text { Entire company }\end{array}$ & 42 & $2,3,4,5,7,9$ & 60 \\
& $2,3,6,7,16,17,18$, & 42 & 8,10 & 20 \\
IT system & 19 & & & \\
Business program & 9,15 & 10.5 & - & 0 \\
Individual business areas & 12 & 5 & - & 0 \\
Projects & - & 0 & 1 & 10 \\
Total & - & 0 & 6 & 10 \\
\hline
\end{tabular}




\subsection{Presence of a digital strategy}

First, the study looked at whether companies had one or more digital strategies (Table 3).

The study showed that the majority of SMEs had no digital strategy (63\%). Of these, half did not even have their own digital strategy planned in the future, while the other half had ideas about digital strategies, but had not written them down. By contrast, $21 \%$ of SMEs had a broader digital strategy for the entire enterprise and $16 \%$ had several subordinate sub-strategies instead.

For the LSEs, the majority $(60 \%)$ had an overall digital strategy. Again, however, in each case one in five companies stated that they either had no fixed digital strategy or had several sub-strategies.

The study revealed that the SMEs, in particular, did not have digital strategies. The derivation of such a strategy was also not planned here, because, as a result of the size of the companies, "we have ideas that we act on, but simply did not need any formulation" (SME 5). The companies had "many individual topics that could be subsumed under a digital strategy" (SME 11), which had not been done for capacity and time reasons. In the LSEs, on the other hand, it was imperative to have an "all-encompassing [digital] strategy" (LSE 1), which took into account the "vision, mission and focus issues of different business units and different markets in different forms" (LSE 7). Because of their size all of the companies needed to strategically align their entire business to digital development to ensure a successful digital transformation.

\subsection{Use of technologies}

The first component of a digital strategy is the use of new technologies and their strategic role. The companies were able to describe which new technologies they wanted to implement in the future. For this reason, the technological changes for SMEs and LSEs are presented in the following table (Table 4).

The results of the study show that the SMEs were primarily focusing on basic, new software solutions (47\%). Moreover, technological changes in the entire IT infrastructure $(10.5 \%)$, or new, more modern technology for specific business areas $(10.5 \%)$, were understood in SMEs as needing technological adjustments. At the same time, the SMEs were trying to make improvements through new technology-

Table 3 Presence of a digital strategy

\begin{tabular}{|c|c|c|c|c|}
\hline & SMEs & $\begin{array}{l}\text { Percentage } \\
(\%)\end{array}$ & LSEs & $\begin{array}{l}\text { Percentage } \\
(\%)\end{array}$ \\
\hline No and it is not planned & $1,2,9,12,15,17$ & 31.5 & - & 0 \\
\hline $\begin{array}{l}\text { No, not yet formulated, but ideas } \\
\text { available }\end{array}$ & $\begin{array}{l}5,10,11,13,14 \\
16\end{array}$ & 31.5 & 8,10 & 20 \\
\hline Yes, an overarching strategy & $3,6,7,8$ & 21 & $\begin{array}{l}1,2,3,4,7 \\
\quad 9\end{array}$ & 60 \\
\hline Yes, several sub-strategies & $4,18,19$ & 16 & 5,6 & 20 \\
\hline Total & 19 & 100 & 10 & 100 \\
\hline
\end{tabular}


Table 4 Use of technologies

\begin{tabular}{lllll}
\hline & SMEs & $\begin{array}{l}\text { Percentage } \\
(\%)\end{array}$ & LSEs & $\begin{array}{l}\text { Percentage } \\
(\%)\end{array}$ \\
\hline $\begin{array}{l}\text { New software } \\
\text { Entire IT infrastructure }\end{array}$ & $1,2,3,4,5,13,15,17,18$ & 47 & 8 & 10 \\
$\begin{array}{l}\text { New/modern technologies for special } \\
\text { business areas }\end{array}$ & 8,9 & 10.5 & $3,5,6,7$ & 40 \\
$\begin{array}{l}\text { Prototyping and benefits of } \\
\text { prototypes }\end{array}$ & 6 & 10.5 & 2,10 & 20 \\
$\begin{array}{l}\text { Data-based solutions } \\
\text { Cloud-based tools }\end{array}$ & 7 & 5 & 9 & 10 \\
$\begin{array}{l}\text { No special technologies } \\
\text { Total }\end{array}$ & 19 & 5 & - & 0 \\
\hline
\end{tabular}

based prototypes (5\%). Even with data-based solutions $(5 \%)$ to cloud-based tools $(5 \%)$, it is evident that the SMEs were adapting their technological structures. Nevertheless, $16 \%$ of companies were also ready to develop a digital strategy without new, special technologies.

In the LSEs, however, the vast majority of companies were linking their digital strategies to technological changes across the entire IT infrastructure (40\%). However, new, modern technologies for special business areas $(20 \%)$, cloud-based solutions $(20 \%)$, new software $(10 \%)$ or new technical prototypes $(10 \%)$ were also associated with the design of technologies within digital strategies.

In summary, the development of a digital strategy in the SMEs was primarily linked to new software solutions "for automation" (SME 2 and SME 3) and "for new graphic visual solutions" (SME 5). For the LSEs, on the other hand, digital strategies primarily involved aspects of technological solutions that affect the entire IT infrastructure. In this respect, it can be stated that in the SMEs the digital transformation could be implemented by new software because of the smaller company size, while the LSEs were focusing on the "standardization and reduction of [corporate-wide] IT infrastructure" (LSE 6). The literature also comes to the same result. New software solutions are also particularly helpful for SMEs, since these solutions can produce selective improvements and often no company-wide and uniform IT infrastructure is required. In LSEs, on the other hand, a uniform solution for their IT infrastructure and data basis is crucial for strategic decisions and for their long-term orientation. That is precisely why LSEs primarily try to achieve a total optimization of the company-wide IT infrastructure with new technical solutions (Becker et al. 2018).

\subsection{Changes in value creation}

To be able to compare the changes in the value added, it must first be shown how the value added has hitherto occurred in the SMEs and LSEs (Table 5). 
Table 5 Current way of adding value

\begin{tabular}{lllll}
\hline & SMEs & $\begin{array}{l}\text { Percentage } \\
(\%)\end{array}$ & $\begin{array}{l}\text { LSEs } \\
\text { Percentage } \\
(\%)\end{array}$ \\
\hline $\begin{array}{l}\text { Added value through physical } \\
\text { products }\end{array}$ & $\begin{array}{c}2,4,5,6,10,11,12,13, \\
14,17,18,19\end{array}$ & $4,5,9$ & 30 \\
$\begin{array}{l}\text { Added value through combination of } \\
\text { products and services }\end{array}$ & $3,7,9,15$ & 21 & $1,7,10$ & 30 \\
$\begin{array}{l}\text { Added value through services } \\
\text { Total }\end{array}$ & $1,8,16$ & 16 & $2,3,6,8$ & 40 \\
& 19 & 100 & 10 & 100 \\
\hline
\end{tabular}

In particular, in the SMEs, physical products $(63 \%)$ had largely been generating added value. In just one-fifth of the companies, the value was created through a combination of physical products and services. Of the companies, $16 \%$ were achieving their added value through services alone.

In the LSEs, value creation was very heterogeneous, as companies were offering both physical products (30\%) and services $(40 \%)$, or a combination of the two $(30 \%)$.

Within this category, the participants were asked to indicate which the main source of sales is creating value. There may also be other products or services and their combinations in the individual companies, which are not to be regarded as the main way of adding value. The study of Hess et al. (2016) also shows that companies can add value in different ways. At this point, it must, therefore, be pointed out again that the current way of generating added value in the SMEs and LSEs is only valid for the present sample. But, finally, the present study shows a rough overview of a certain tendency.

The following table shows the change within the companies' value added (Table 6).

The study revealed that the majority $(31.5 \%)$ of SMEs saw no changes in their value added. However, in each case $16 \%$ indicated that they would create value in the future through new services, or a combination of new products and services. At the same time, the study showed that value creation would also change with new

Table 6 Changes in value creation

\begin{tabular}{lllll}
\hline & SMEs & Percentage $(\%)$ & LSEs & Percentage (\%) \\
\hline No changes in the value added & $8,9,10,12,15,19$ & 31.5 & 6 & 10 \\
New services & $5,7,18$ & 16 & - & 0 \\
$\begin{array}{l}\text { New combination of products } \\
\text { and services }\end{array}$ & $6,13,14$ & 16 & $2,3,5,7$ & 40 \\
New and more data & 2,16 & 10.5 & 1,10 & 20 \\
New products & 3,4 & 10.5 & 8 & 10 \\
New technologies & 11,17 & 10.5 & 4,9 & 20 \\
Higher networking of production & 1 & 5 & - & 0 \\
Total & 19 & 100 & 10 & 100 \\
\hline
\end{tabular}


and more data, new products and new technologies (in each case 10.5\%). Improved networking within production would also change the value added $(5 \%)$.

In LSEs, on the other hand, it was evident that value added would change, especially through the combination of new products and services (40\%). Again, participants indicated that value added would change with new data (20\%), new technologies (20\%) and new products (10\%). However, $10 \%$ said that they did not expect any change in value added.

The study showed that the SMEs were achieving their added value through physical products, and this will not change in the near future. At best, "products will no longer be available individually, but as a bundle of products with the service" (SME 13). By contrast, LSEs were generating very heterogeneous value added through products, services, or a combination of both. This will continue to deepen in the future. With SMEs and LSEs, the generation of new and larger amounts of data will change the value added, since "data will merge with products and be available in real time" (SME 16). At the same time, the development or integration of new technologies within companies means that value creation will tend to change, "enabling better and more timely tracking of goods flows through digital tools in production and the entire supply chain, anticipating needs, or enabling faster sales in sales" (LSE 4). As already stated, digitalization has an impact on the change in the context of achieving added value (Bharadwaj et al. 2013; Klötzer and Pflaum 2017; Sebastian et al. 2017). The present study also shows the tendency to change the added value by both SMEs and LSEs adapting their type of added value to the new situational conditions. It must also be pointed out here that this is a change in the main source of sales of the respective companies.

\subsection{Structural changes}

In addition, the study examined changes in the organizational structure of SMEs and LSEs resulting from new technologies and changed value added. Table 7 shows the results of the study.

Within the SMEs, digitalization will change the organizational structure to require flatter and more flexible hierarchies (37\%). However, 37\% of companies were already positioned for digital transformation, meaning that no changes in the organizational structure were required. In $16 \%$ of the companies, however, new

Table 7 Structural changes

\begin{tabular}{lllll}
\hline & SMEs & $\begin{array}{l}\text { Percentage } \\
(\%)\end{array}$ & LSEs & $\begin{array}{l}\text { Percentage } \\
(\%)\end{array}$ \\
\hline Flatter and more flexible hierarchies & $2,3,7,8,10,16,19$ & 37 & $5,7,8$ & 30 \\
No changes & $4,5,11,12,13,14,17$ & 37 & $3,6,9,10$ & 40 \\
$\begin{array}{l}\text { Founding or enlargement of certain } \\
\quad \text { departments }\end{array}$ & $6,9,15$ & 16 & 4 & 10 \\
$\begin{array}{l}\text { Founding cross-divisional teams } \\
\text { Total }\end{array}$ & 1,18 & 10.5 & 1,2 & 20 \\
\hline
\end{tabular}


departments were being set up or existing areas expanded for digitalization. Furthermore, cross-divisional teams $(10.5 \%)$ were being created for this purpose.

In the LSEs too, digitalization required flatter and more flexible hierarchies in $30 \%$ of companies. At the same time, new areas for digitalization were being set up (10\%), or existing ones $(20 \%)$ expanded. The majority (40\%), on the other hand, were already well positioned within the structure.

The study showed that digitalization requires flatter and more flexible structures since digital transformation requires "faster action hierarchies" (SME 16). At the same time, "certain levels of hierarchy more or less fall away because of organization and communication across the enterprise" (SME 3). However, the study also showed that most of the SMEs and LSEs were already well structured for digital changes, and it is more crucial to "put the right people in the right places to achieve a clean communication and a good interaction" (SME 3) and a "you culture" (SME 17). Against the background of the "Digital Transformation Framework" it is striking that some companies see no need to change their organizational structure. The literature shows that most SMEs, in particular, are already organized very flat, agile and flexible. LSEs, on the other hand, are sometimes still very hierarchically structured, which means that a change in the organizational structure is made very challenging (Nowotarskia and Paslawskia 2015). However, the present study has shown that the organizational structure in most SMEs as well as in LSEs is already suitable for implementing the digital transformation.

\subsection{Financial aspects}

The changes that result from digitalization in the context of technology, value added and organizational structure must eventually be financially viable. For this reason, the study examined the financing of digitalization in the SMEs and LSEs. The following table shows the results (Table 8).

Table 8 Financial aspects

\begin{tabular}{lllll}
\hline & SMEs & $\begin{array}{l}\text { Percentage } \\
(\%)\end{array}$ & LSEs & $\begin{array}{c}\text { Percentage } \\
(\%)\end{array}$ \\
\hline $\begin{array}{l}\text { Generated sales through products and } \\
\quad \text { services }\end{array}$ & $\begin{array}{c}4,5,6,9,10,11,12,13, \\
16,18,19\end{array}$ & 58 & $2,4,7$, & 50 \\
Internally determined budgets & $1,8,14,15$ & 21 & $3,5,9$ & 30 \\
$\begin{array}{l}\text { Financing by shareholders or } \\
\quad \text { investors }\end{array}$ & 2,7 & 10.5 & - & 0 \\
$\begin{array}{l}\text { Governmental funding } \\
\text { Internal financing, but with the help } \\
\quad \text { of external partners }\end{array}$ & - & 5 & 6 & 10 \\
Not specified & 17 & 0 & 1 & 10 \\
Total & 19 & 5 & - & 0 \\
\hline
\end{tabular}


The study showed that the majority (58\%) of SMEs were financing changes in digital transformation through generated sales through products and services. Even with predetermined internal budgets, approximately one-fifth of the companies were financing digitalization. Funding by shareholders or investors $(10.5 \%)$ or governmental funding (5\%) was possible here. One participant of the study (SME 17) did not comment on this.

Moreover, in the LSEs, digitalization was financed by generated sales through products and services $(50 \%)$ or internally fixed budgets (30\%). Governmental funding $(10 \%)$, or a combination of internal financing with external partners $(10 \%)$, was possible in the LSEs.

The results of the study show that both SMEs and LSEs were financing the required transformation of digitalization through generated sales through products and services or through clearly defined budgets of the period. The companies were ensuring that digitalization as the "internal investment theme" (LSE 4) was using only "the resources available (...) for change" (SME 16), enabling companies to "operate profitably and cost-effectively" (SME 6). However, even for "larger purchases" (SME 9), companies could resort to support from governmental funding or from shareholders or investors.

Overall, the study shows that digitalization is financed by the cash flows generated from sales or by previously defined budgets. Hardly any SME or LSE uses other alternatives, which means that it can be concluded that digitalization can be viewed as an internal, planned project. The study by Hess et al. (2016) came to the same conclusion that companies use internal funds for the digitalization and digital to finance the digital transformation program.

\section{Discussion and derivation of digital strategies for SMEs and LSEs}

The present findings have shown that there were essential differences in the design of the digital strategies in the SMEs and LSEs examined. Table 9 gives a direct comparison between ideal types of digital strategies for SMEs and LSEs.

Table 9 Composition of ideal digital strategies for SMEs and LSEs

\begin{tabular}{|c|c|c|}
\hline & SMEs & LSEs \\
\hline Purpose of the digital strategy & $\begin{array}{l}\text { Internal and external processes and } \\
\text { whole company }\end{array}$ & Internal and external processes \\
\hline Use of technologies & New software & $\begin{array}{l}\text { Optimization of the entire IT } \\
\text { infrastructure }\end{array}$ \\
\hline $\begin{array}{l}\text { Nature of future value } \\
\text { creation }\end{array}$ & $\begin{array}{l}\text { Added value through physical } \\
\text { products }\end{array}$ & $\begin{array}{l}\text { New combination of products } \\
\text { and services }\end{array}$ \\
\hline $\begin{array}{l}\text { Nature of futural } \\
\text { organizational structure }\end{array}$ & Flatter and flexible hierarchies & Flatter and flexible hierarchies \\
\hline Financial aspects & Generated sales and derived budgets & $\begin{array}{l}\text { Generated sales and derived } \\
\text { budgets }\end{array}$ \\
\hline
\end{tabular}


The study has shown that companies of different sizes and from various industries have largely derived and integrated a digital strategy for themselves. The results of the study make it clear that the purpose of such a strategy depends on the size of the company because while the focus in SMEs is primarily on the adaption of all internal and external processes to the optimization of the entire company, in LSEs the core of the digital strategy is merely the adaption of all processes, but not the entire company, with its business models. To fulfill these purposes, adaption is required within the use of technologies, the nature of future value creation, the organization of the future organizational structure and the financing of digitalization. While SMEs primarily need new software solutions as part of the technology, the focus of LSEs is on technologies that contribute to the optimization of the entire IT infrastructure. For the added value of companies, this means that in the future SMEs will continue to primarily create value through physical products. By contrast, LSEs are already very heterogeneously positioned, with new combinations of products and services leading to new added value in the future. These changing technologies and changed ways of adding value require flatter and more flexible hierarchies, in both SMEs and LSEs, to create a basis that can react as fast as possible. At the same time, the study shows that these necessary changes in SMEs and LSEs are primarily implemented through generated sales through products and services or through clearly defined budgets since the digital transformation is an internal investment theme.

\section{Conclusion, limitations and future research}

With these results, the present study contributes to the current research on digital strategies. The existing publications will be enhanced by new insights through the special focus on SMEs and LSEs. The findings of this study have shown that SMEs and LSEs do not always have digital strategies, but they need such a strategy for a holistic and successful digital transformation. However, if those companies have digital strategies, there are essential differences in their design.

At this point, however, some limitations of the present study must be pointed out. Due to the qualitative research approach, generally valid statements are only possible to a limited extent (Myers 2013). To relativize the limitations of this approach, an approach with expert interviews with several companies in different industries and different sizes was used. The data obtained from the expert interviews were triangulated with secondary data. This enabled the stability and reliability of the data to be supported. The analysis of the data was finally carried out by two independent researchers, who always critically questioned the statements while carrying out the study.

The findings of the study are relevant not only from the point of view of science but also from a practical point of view, because the present contribution also serves as a decision support for the management in SMEs and LSEs, insofar as these companies need help in implementing such a digital strategy. Managers can therefore use the derived design of these strategies to set up their company in the long term so that it can successfully carry out the digital transformation and thus 
survive in the digital age. Nonetheless, the "black box" around the digital strategies in SMEs and LSEs requires further research because the results of the study should first be reviewed within quantitative empiricism. At the same time, it was intended to examine which instruments could be used to successfully implement such a digital strategy.

Open Access This article is licensed under a Creative Commons Attribution 4.0 International License, which permits use, sharing, adaptation, distribution and reproduction in any medium or format, as long as you give appropriate credit to the original author(s) and the source, provide a link to the Creative Commons licence, and indicate if changes were made. The images or other third party material in this article are included in the article's Creative Commons licence, unless indicated otherwise in a credit line to the material. If material is not included in the article's Creative Commons licence and your intended use is not permitted by statutory regulation or exceeds the permitted use, you will need to obtain permission directly from the copyright holder. To view a copy of this licence, visit http:// creativecommons.org/licenses/by/4.0/.

\section{References}

Amit, R., and C. Zott. 2001. Value creation in e-business. Strategic Management Journal 22 (6-7): 393-520.

Arnold, C., D. Kiel, and K.-I. Voigt. 2016. How the industrial Internet of things changes business models in different manufacturing industries. International Journal of Innovation Management 20 (8): 1-25.

Banker, R., I. Bardhan, H. Chang, and S. Lin. 2006. Plant information systems, manufacturing capabilities, and plant performance. MIS Quarterly 30 (2): 315-337.

Becker, W., O. Schmid, and T. Botzkowski. 2018. Role of CDOs in the digital transformation of SMEs and LSEs. An empirical analysis. 51st Hawaii international conference on system sciences: 4534-4543.

Bharadwaj, A., O.A. El Sawy, P.A. Pavlou, and N. Venkatraman. 2013. Digital business strategy: toward a next generation of insights. MIS Quarterly 37 (2): 471-482.

Bidan, M., F. Rowe, and D. Truex. 2012. An empirical study of IS architectures in French SMEs: integration approaches. European Journal of Information Systems 21 (3): 287-302.

Bouwman, H., M. de Reuver, and S. Nikou. 2017. The impact of digitalization on business models: how IT artefacts, social media, and big data force firms to innovate their business model. 14th international telecommunications society (ITS) Asia-Pacific regional conference 1-20.

Cohen, J.A. 1960. Coefficient of agreement for nominal scales. Educational and Psychological Measurement 20 (1): 37-46.

Diamandis, P.H. 2015. The World in 2025: 8 predictions for the next 10 years. Singularity: Singularity University.

Doz, Y. 2011. Qualitative research for international business. Journal of International Business Studies 42 (5): 582-590.

Dubé, L., and G. Paré. 2003. Rigor in information systems positivist case research: current practices, trends, and recommendations. MIS Quarterly Executive 27 (4): 597-636.

Eisenhardt, K.M. 1989. Building theories from case study research. Academy of Management Review 14 (4): 532-550.

Eisenhardt, K.M., and M.E. Graebner. 2007. Theory building from cases: opportunities and challenges. Academy of Management Journal 50 (1): 25-32.

Fitzgerald, M., N. Kruschwitz, D. Bonnet, and M. Welch. 2013. Embracing digital technology. Cambridge: MIT Sloan Management Review.

Foddy, W. 1993. Constructing questions for interviews and questionnaires. Cambridge: University Press.

Haffke, I. 2017. The implications of digital business transformation for corporate leadership, the IT function, and business-IT alignment. Technical University Darmstadt: Dissertation

Haffke, I., B. Kalgovas, and A. Benlian. 2016. The role of the CIO and the CDO in an organization's digital transformation. 37th international conference on information systems 1-20.

Hayes, A.F., and K. Krippendorff. 2007. Answering the call for a standard reliability measure for coding data. Communication Methods and Measures 1 (1): 77-89. 
Hess, T., C. Matt, A. Benlian, and F. Wiesböck. 2016. Options for formulating a digital transformation strategy. MIS Quarterly Executive 15 (2): 123-139.

Hirschheim, R., and R. Sabherwal. 2001. Detours in the path toward strategic information system alignment. California Management Review 44 (1): 87-108.

Horlacher, A., and T. Hess. 2016. What does a chief digital officer do? Managerial tasks and roles of a new c-level position in the context of digital transformation. 49th Hawaii international conference on system sciences 5126-5135.

Klötzer, C., and A. Pflaum. 2017. Toward the development of a maturity model for digitalization within the manufacturing industry's supply chain. 50th Hawaii international conference on system sciences 4210-4219.

Köhler, S., and T. Hess. 2016. The chief digital officer-phantom or pioneer? Study to control the digital transformation of the media industry. Amstelveen: KPMG. (In German).

Kohli, R., and V. Grover. 2008. Business value of IT: an essay on expanding research directions to keep up with the time. Journal of the Association for Information Systems 9 (1): 23-39.

Krippendorff, K. 2004. Content analysis: an introduction to its methodology, 2nd ed. Thousand Oaks: Sage Publications.

Laumer, S., C. Maier, A. Eckhardt, and T. Weitzel. 2016. User personality and resistance to mandatory information systems in organizations: a theoretical model and empirical test of dispositional resistance to change. Journal of Information Technology 31: 67-82.

Lee, Y., J. Shin, and Y. Park. 2012. The changing pattern of SME's innovativeness through business model globalization. Technological Forecasting and Social Change 79 (5): 832-842.

Leischnig, A., S. Woelfl, and B.S. Ivens. 2016. When does digital business strategy matter to market performance?. Thirty 37th international conference on information systems 1-16.

Li, W., K. Lui, M. Beletski, A. Ghobadian, and N. O'Regan. 2016. e-Leadership through strategic alignment: an empirical study of small- and medium-sized enterprises in the digital age. Journal of Information Technology 31 (31): 185-206.

Lucas Jr., H., R. Agarwal, E.K. Clemons, O.A. El Sawy, and B. Weber. 2013. Impactful research on transformational information technology: an opportunity to inform new audiences. MIS Quarterly 37 (2): 371-382.

Matt, M., T. Hess, and A. Benlian. 2015. Digital transformation strategies. Business and Information Systems Engineering 57 (5): 339-343.

Miles, M., and M. Huberman. 1994. Qualitative data analysis: an expanded sourcebook, 2nd ed. Thousand Oaks: Sage Publications.

Mithas, S., A. Tafti, and W. Mitchell. 2016. How a firm's competitive environment and digital strategic posture influence digital business strategy. MIS Quarterly 37 (2): 511-536.

Myers, M.D. 2013. Qualitative research in business and management, 2nd ed. Thousand Oaks: Sage.

Nowotarskia, P., and J. Paslawskia. 2015. Barriers in running construction SME-case study on introduction of agile methodology to electrical subcontractor. Procedia Engineering 122: 47-56.

Pagani, M. 2013. Digital business strategy and value creation: framing the dynamic cycle of control points. MIS Quarterly 37 (2): 617-632.

Porter, M.E., and J.E. Heppelmann. 2015. How smart, connected products are transforming competition. Harvard Business Review 92: 1-10.

Pullen, A., P. de Weerd-Nederhof, A. Groen, M. Song, and O. Fisscher. 2009. Successful patterns of internal SME characteristics leading to high overall innovation performance. Creativity and Innovation Management 18 (3): 209-223.

Reich, B.H., and I. Benbasat. 2000. Factors that influence the social dimensions of alignment between business and information technology objectives. MIS Quarterly 24 (1): 81-114.

Ross, J.W., I.M. Sebastian, and C.M. Beath. 2017. How to develop a great digital strategy. MIT Sloan Management Review 58 (2): 7-9.

Sabherwal, R., and Y. Chan. 2001. Alignment between business and IS strategies: a study of prospectors, analyzers, and defenders. Information Systems Research 12 (1): 11-33.

Sambamurphy, V., A. Bharadwaj, and V. Grover. 2003. Shaping agility through digital options: reconceptualizing the role of information technology in contemporary firms. MIS Quarterly 27 (2): 237-263.

Sebastian, I.M., M. Mocker, J.W. Ross, K.G. Moloney, C.M. Beath, and N.O. Fonstad. 2017. How big old companies navigate digital transformation. MIS Quarterly 16 (3): 197-213.

Sia, S.K., C. Soh, and P. Weill. 2016. How DBS bank pursued a digital business strategy. MIS Quarterly Executive 15 (2): 119-135. 
Siggelkow, N. 2007. Persuasion with case studies. Academy of Management Journal 50 (1): 20-24.

Simon, H. 1992. Lessons from Germany's midsize giants. Harvard Business Review 70: 115-123.

Vey, K., T. Fandel-Meyer, J. Zipp, and C. Schneider. 2017. Learning and development in times of digital transformation: facilitating a culture of change and innovation. International Journal of Advanced Corporate Learning 10 (1): 22-32.

Westermann, G., M. Tannou, D. Bonnet, P. Ferraris, and A. McAfee. 2012. The digital advantage: how digital leaders outperform their peers in every industry, 1-24. Paris: MITSloan Management and Capgemini Consulting.

Wheeler, B. 2002. NEBIC: a dynamic capabilities theory for assessing net-enablement. Information System Research 13 (2): 125-146.

Woodard, C.J., N. Ramasubbu, F.T. Tschang, and V. Sambamurthy. 2013. Design capital and design moves: the logic of digital business strategy. MIS Quarterly 37 (2): 537-564.

Yeow, A., C. Soh, and R. Hansen. 2017. Aligning with new digital strategy: a dynamic capabilities approach. Journal of Strategic Information Systems 27 (1): 43-58.

Yin, R.K. 2014. Case study research: design and method, 5th ed. Thousand Oaks: SAGE Publications Inc.

Publisher's Note Springer Nature remains neutral with regard to jurisdictional claims in published maps and institutional affiliations. 